\title{
The seismic response to mining during the extraction of the Thuthukani shaft pillar, Kloof Operations, South Africa
}

\author{
R.T. Masethe1, ${ }^{2}$, R.J. Durrheim ${ }^{1}$ and M.S.D. Manzi ${ }^{1}$ \\ 1University of the Witwatersrand, South Africa \\ 2Sibanye-Stillwater Limited, South Africa
}

\begin{abstract}
All seismic data recorded since the extraction of the Thuthukani shaft pillar commenced in January 2007, has been analysed. Seismicity was compared in two fiveyear periods (1 January 2007 to 30 November 2012 and 1 December 2012 to 31 July 2017). It was found there was an increase in the rate of seismicity and the maximum magnitude $\left(\mathrm{M}_{\max }\right)$ from 2.7 to 3. 2.. Strategies to mitigate the seismic risk during shaft extraction are discussed in this paper.
\end{abstract}

\section{INTRODUCTION}

The study area is located in Thuthukani mine, part of the Kloof Operation, which is owned and operated by Sibanye Stillwater (See Figure 1). Gold-bearing quartz pebble conglomerate ore bodies (locally known as reefs) are mined. The primary ore body is the Ventersdorp Contact Reef (VCR); secondary ore bodies include the Middelvlei Reef (MR), Kloof Reef (KR) and the Libanon Reef (LR). The VCR has been extensively mined from Thuthukani shaft at depths between $2000 \mathrm{~m}$ and $3500 \mathrm{~m}$ during the last forty years. The No. 1 shaft at Thuthukani extends to a depth of $2023 \mathrm{~m}$ below surface, while the 1 subvertical (SV) and 2 SV shafts, extend to depths of 2773 and $3306 \mathrm{~m}$, respectively.

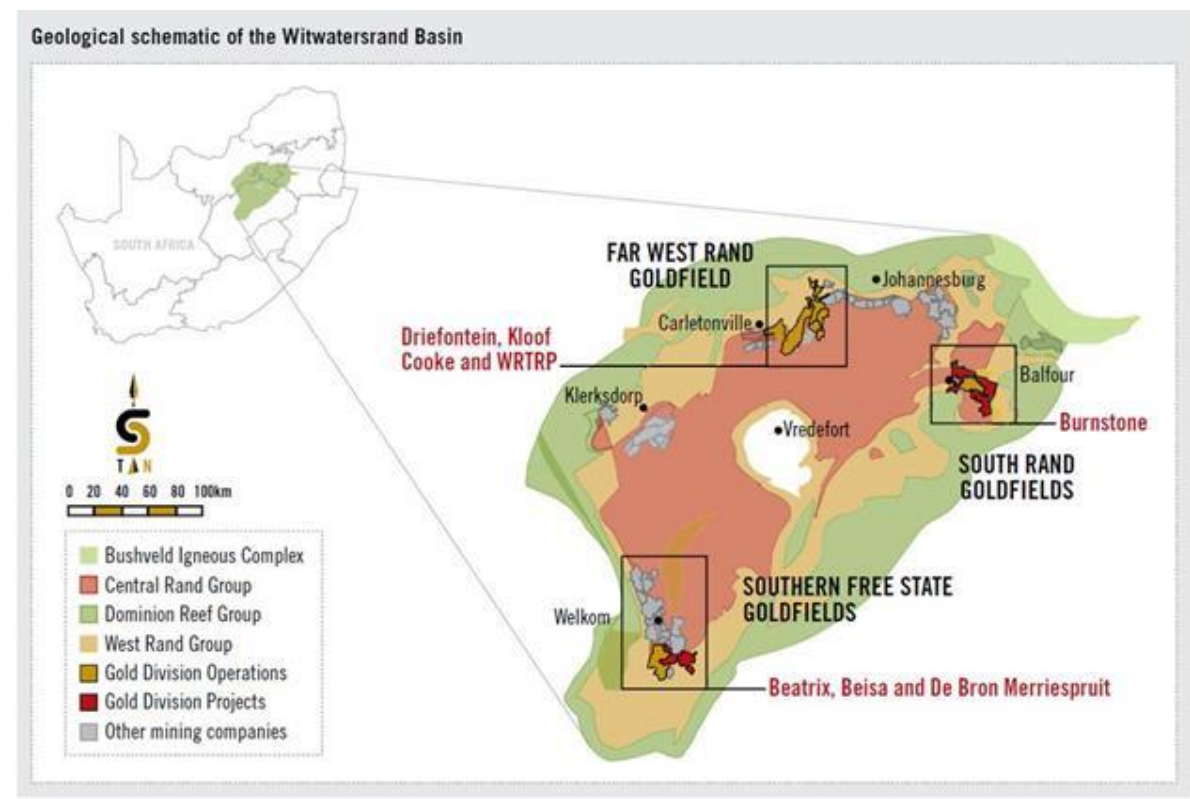

Figure 1. Geological map of the Witwatersrand Basin indicating the location of Kloof Operations (after Dankert and Hein (2010) 


\section{Shaft pillar extraction strategy}

The originally proposed shaft pillar extraction layout was a mini-longwall with overhand mining faces. The layout was designed to have two $30 \mathrm{~m}$ dip pillars on each side of the shafts and four $40 \mathrm{~m}$ strike stability pillars Maritz (2007). Pillars were placed so that the span on both the strike and the dip pillars would not exceed $200 \mathrm{~m}$. A $20 \mathrm{~m}$ bracket pillar was proposed to protect the major geological structure. In 2008, an analysis from the borehole data was obtained and indicated a weaker rock mass than originally anticipated, suggesting that both sub-vertical shafts would fail Naicker (2013). The reassessment of the Thuthukani shaft pillar extraction project resulted in the proposed extraction sequence shown in Figure 2.

Extraction of ore in the shaft pillar started in January 2007 (See Figure 2). Three major geological structures traverse the shaft pillar: the Venterspost Dyke, the Tear Fault and Shaft Fault. Dyke intrusions are associated with both the Tear and the Shaft faults. A bottle shaped shaft protection pillar was designed to protect the four-shaft system $(1,1 \mathrm{SV}, 1 \mathrm{SV}$ Vent and $2 \mathrm{SV})$ during the initial mining around these 4 shafts. It measures approximately $680 \mathrm{~m}$ on strike and $970 \mathrm{~m}$ on dip. The final block of unmined VCR ground (the final pillar) to remain after the pillar extraction is coloured in pink in Figure 2. Four 30-m-wide dip pillars, together with a block of ground left unmined to clamp the major geological structures, provide regional stability for the mining in the shaft pillar. The sequential grid layout, mining in the strike direction with an overhand configuration, was designed to keep the average Energy release rate below $30 \mathrm{MJ} / \mathrm{m}^{2}$, Jager and Ryder (1999). The characteristics and the geology of the Thuthukani shaft are summarised in Table I.

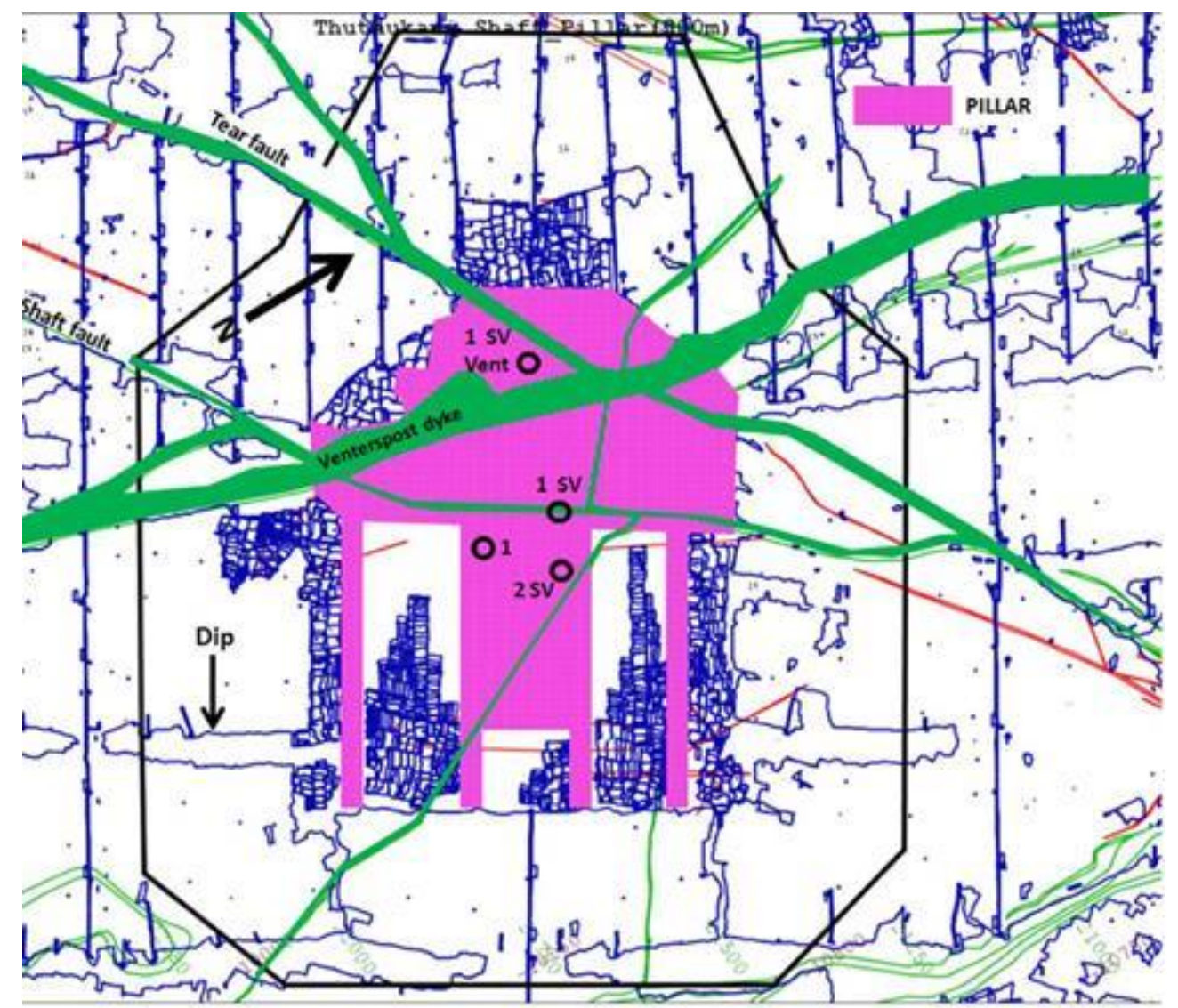

Figure 2 - Plan view of the Thuthukani shaft pillar showing the Permanent Pillar, four dip pillars, and the Venterspost Dyke and the Tear and Shaft faults (both containing dyke material). 1 - Main shaft, 1 SV - 1 Subvertical shaft, 1 SV Vent - 1 Sub-vertical ventilation shaft, 2 SV - 2 Sub-vertical shaft. Black line defines the polygon of analysis 
Table I. Characteristics of the Thuthukani shaft pillar (extraction area)

\begin{tabular}{|l|l|}
\hline Reef & Ventersdorp Contact Reef (VCR) \\
\hline Stoping width & $1.2 \mathrm{~m}$ \\
\hline Footwall & Quartzite of the Mondeor formation \\
\hline Hangingwall & Basalt of the Alberton or Westonaria Formations \\
\hline Area of pillar $\left(\mathrm{m}^{2}\right)$ & 659600 \\
\hline Strike & $45^{0}$ \\
\hline Dip & $\sim 32^{0}$ \\
\hline Max strike span of pillar $(\mathrm{m})$ & 680 \\
\hline Max dip span of pillar $(\mathrm{m})$ & 970 \\
\hline Depth below surface $(\mathrm{m})$ & -2453 \\
\hline Mining Method & Sequential grid with dip pillar \\
\hline Regional support & Dip pillars (30m in width) \\
\hline Inner pillar $\left(\mathrm{m}^{2}\right)$ & No inner pillar, but large unmined block \\
\hline
\end{tabular}

\section{GEOLOGY AND GEOTECHNICAL PROPERTIES}

The geology of the Witwatersrand Supergroup has been described by many authors (See Dankert and Hein (2010) and Manzi et al (2013)), and is summarized in the geological cross section shown in Figure 3. The VCR is the primary ore body in the study area. It is a member of the Venterspost Formation, which is the basal unit of the Ventersdorp Supergroup. The hangingwall of the VCR consists of basalt. Two types of basalt are found on Kloof Operations: strong and competent basalts of the Alberton Formation, and weaker komatiitic basalts of the Westonaria Formation (WAF). Most of the Thuthukani shaft pillar is in the WAF area; it has a high density of cooling fractures and is very blocky, hence poor hangingwall conditions were expected. The immediate footwall rocks are mostly competent Elsburg quartzites of the Mondeor Formation, Witwatersrand Supergroup. The basalts and quartzites have very different physical properties. The most important property for rock engineering design is the uniaxial compressive strength (UCS). Rock strength tests on 28 samples from Kloof Operations showed that the UCS can vary significantly Chen (2007). The results of the rock strength tests are presented in Table II.

Table II. Rock strength in UCS for Kloof Operations.Van der Heever and Ryder (2007)

\begin{tabular}{|c|c|c|c|c|}
\hline Formation & Rock Type & $\begin{array}{c}\text { UCS (MPa) } \\
\text { Low }\end{array}$ & $\begin{array}{c}\text { UCS (MPa) } \\
\text { Mean }\end{array}$ & $\begin{array}{c}\text { UCS (MPa) } \\
\text { High }\end{array}$ \\
\hline Alberton & Basalt & 220 & 260 & 300 \\
\hline Westonaria & Komatiitic basalt & 56 & 88 & 120 \\
\hline Mondeor & Quartzite & 220 & 260 & 300 \\
\hline
\end{tabular}




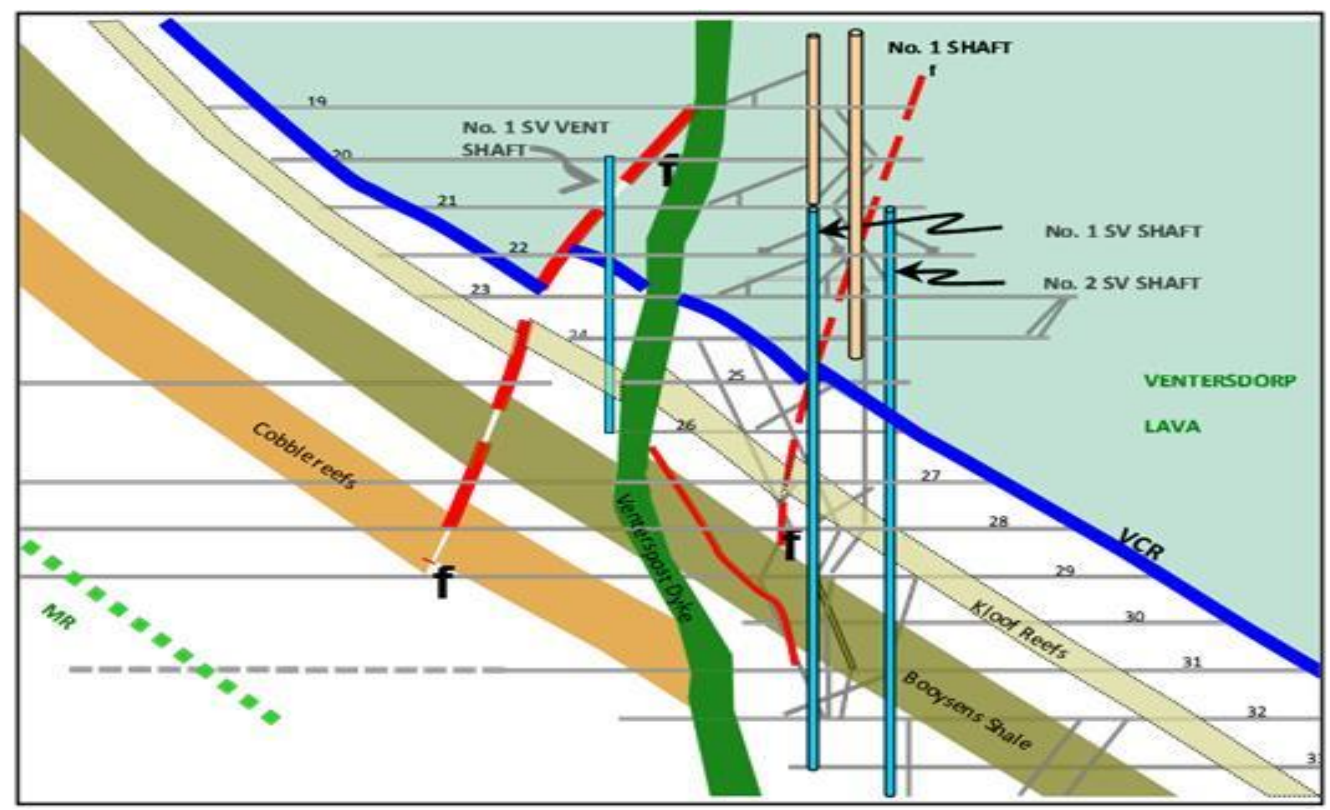

Figure 3 - Schematic stratigraphic section view of the Thuthukani shaft pillar highlighting geological structures that might influence mining (after Naicker (2013). VCR: Venterspost Contact Reef, MR: Middelvlei Reef

\section{MINE DESIGN AND SEISMIC MONITORING STRATEGIES}

\section{Mine design strategies}

As mining progresses, shaft pillars become more and more susceptible to stress-related problems. The pillar's stability is mostly affected by geological structures, depth, the host rock, mining methods, mining geometry and the extraction volumes. Rules of thumb were developed for the current shaftpillar extraction based on seismic and instrumentation monitoring, stress modelling, underground observation and experience. Naicker (2013) provides a summary of the mining layout and the seismic monitoring measures that have been adopted by Kloof Operations in mining the shaft pillar. These include:

- Design of mining layouts to keep average energy release rate (ERR) values below $30 \mathrm{MJ} / \mathrm{m}^{2}$;

- Design of bracket pillars using numerical modelling to reduce excess shear stress (ESS) on the existing geological structures;

- Managing and control of the face shape index (FSI);

- Application of the $70 \mathrm{~m}$ rock engineering rule when panels are mined towards each other. For example, when two panels mining towards each other are separated by less than $70 \mathrm{~m}$, one panel should be stopped;

- Limiting the mining rate and avoiding the concentration of mining;

- Introduction of the centralised blasting and the removal of the night shift;

- Preconditioning of all mining panels to reduce the incidence of face bursts; and

- Seismic monitoring and a comprehensive monitoring program using various types of instrumentation.

\section{Seismic monitoring system}

The current Institute of Mine Seismology (IMS) seismic network on the Kloof Operations consists of thirty-seven $4.5 \mathrm{~Hz}$ three-component geophones with a sample rate at $6 \mathrm{kHz}$. The mine wide network covers approximately $202 \mathrm{~km}^{2}$ of the mine's lease area (See Figure 4 and Figure 5). To optimise the accuracy of hypocentre locations, some geophones were located at sites that are some distance away from the reef planes, as allowed by the mine's shaft and development infrastructure. 
The Thuthukani shaft pillar covers an area of $0.66 \mathrm{~km}^{2}$, with eleven geophones in close proximity (See Figure 4). Geophone sites were selected to provide the optimum sensitivity and location accuracy (within metres) in the area of interest. However, the minimum recorded magnitude of events is dependent on maintenance of the underground sites.

\section{Modelled system sensitivity}

The sensitivity of the system in each area is proportional to the number and proximity of installed geophones. The idealised system sensitivity for the Thuthukani shaft pillar is depicted in Figure 4. A maximum sensitivity (magnitude -0.9) is achievable in this block of ground, which according to Jager and Ryder (1999), is adequate for location, prevention and control requirements.

\section{Modelled system location accuracy}

The current system location accuracy on the $X Y$ plane is shown in Figure 5. Should an additional geophone be installed on 18 level (to improve accuracy in the Z-direction), the location accuracy would be adequate for location, prevention and control requirements.

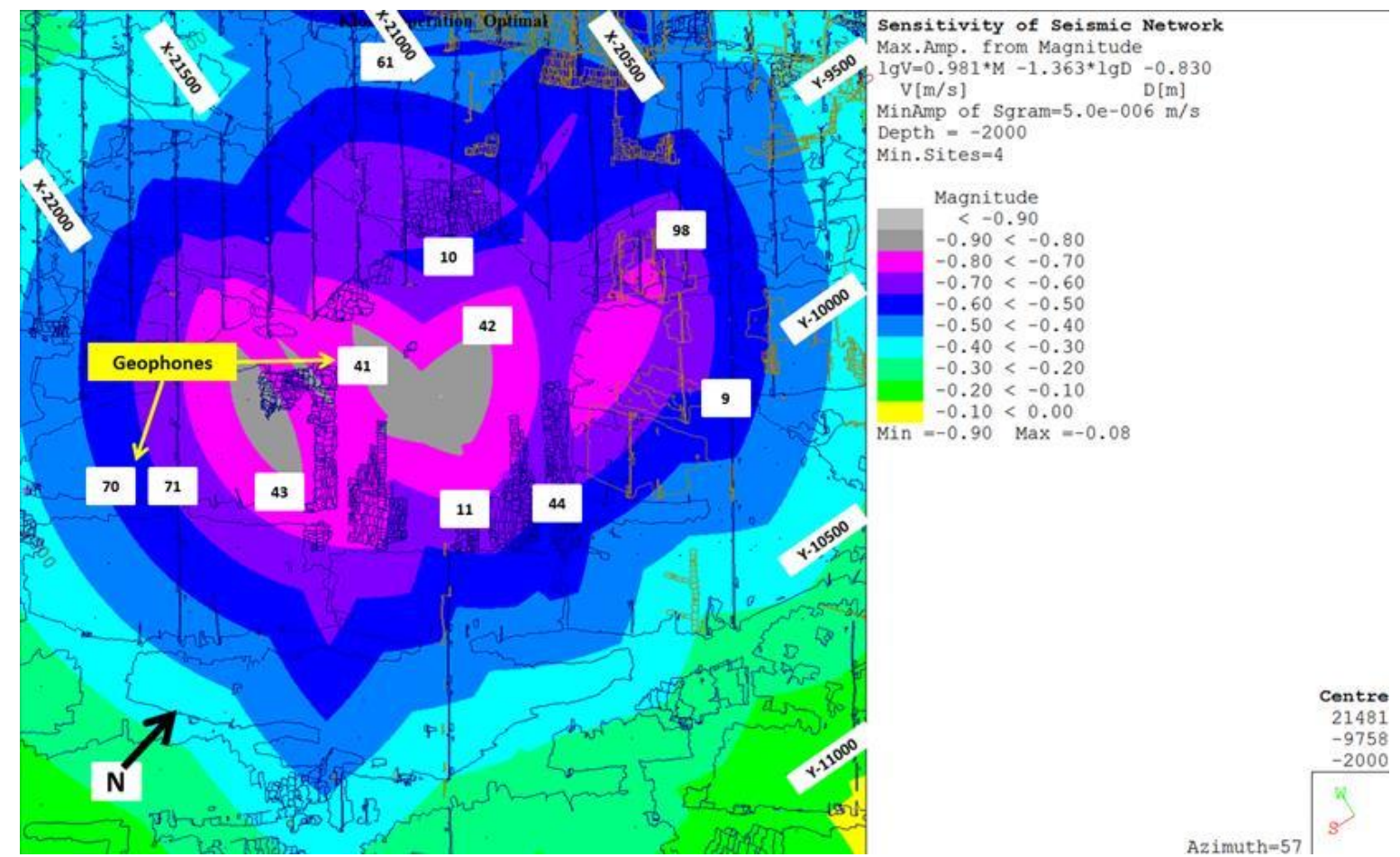

Figure 4. Seismic system sensitivity (if all geophones are operational), which is deemed adequate for short-term seismic hazard identification and long-term strategic planning. Geophones within a shaft pillar are labelled and named. Sensitivity increases towards the centre of the Thuthukani shaft pillar 


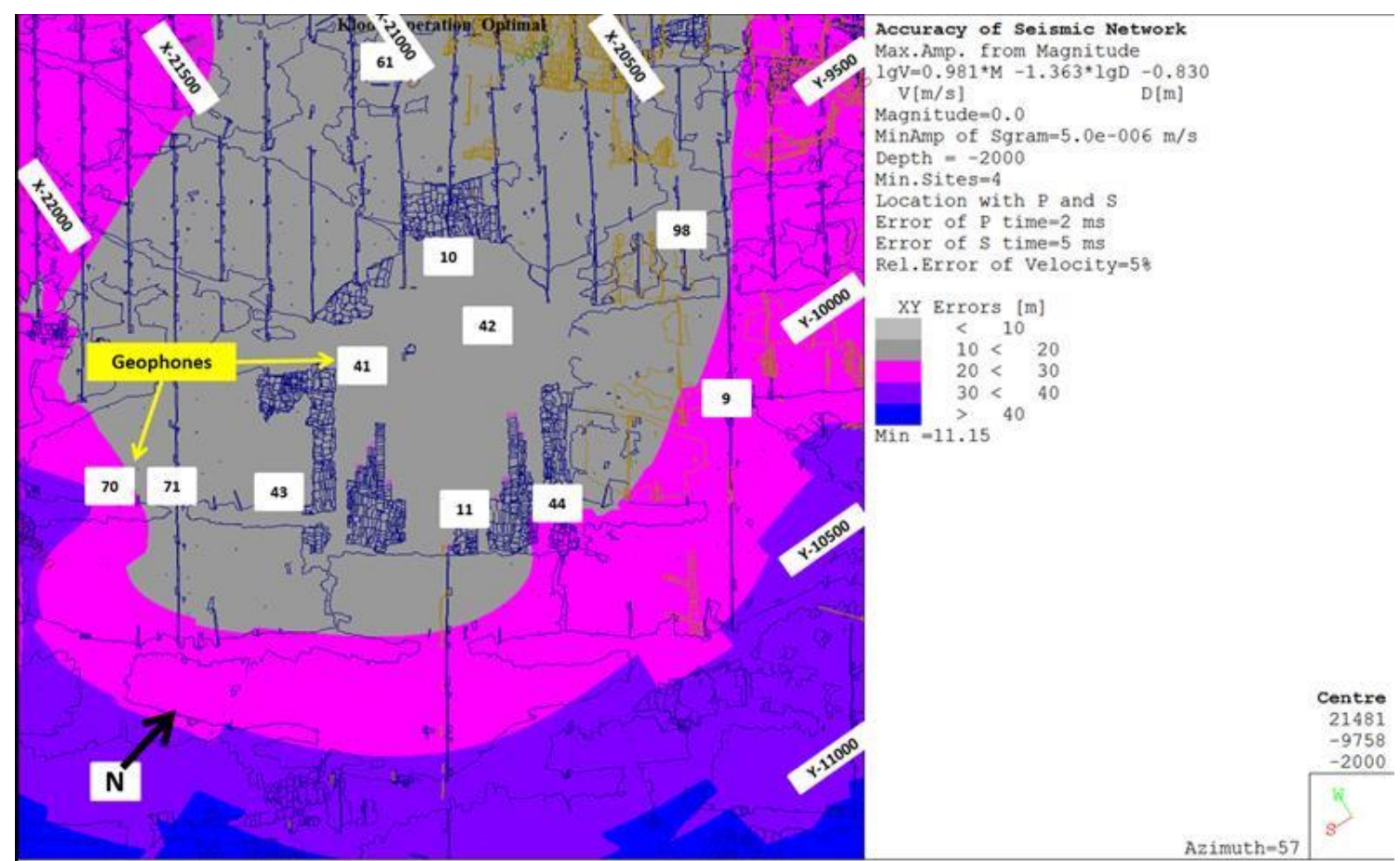

Figure 5. Seismic system location accuracy (if all geophones are operational), which is deemed adequate for shortterm seismic hazard identification and long-term strategic planning. Geophones within a shaft pillar are labelled and named. Sensitivity increases towards the centre of the Thuthukani shaft pillar

\section{RESULTS}

\section{Seismicity data}

The seismic energy release during shaft pillar extraction is governed by factors such as the depth, production volume, mining geometry and the geological structures. The Institute of Mining Seismology (IMS) seismic system recorded 2896 events with $\mathrm{M}_{\mathrm{L}} \geq 0.0$ within the Thuthukani shaft pillar section from 1 January 2007 to 31 July 2017. These are presented in both plan and section views in Figure 6; the colours representing the seismic activity in this plot are based on annual intervals as shown in the legend while the size is represented in terms of the apparent volume of each event. Seismic activity migrates in a North-West direction, in accordance with the general trend of the mining. It is evident that most of the seismic events locate close to the active working areas and the stope horizon. Most events occur just ahead of the mining faces. Several large events have been observed in the abutment of the shaft pillar and far from the mining horizon. For example, a $\mathrm{M}_{\mathrm{L}} 3$ event in the hangingwall was located $170 \mathrm{~m}$ away from the Venterspost dyke (See Figure 6a). 


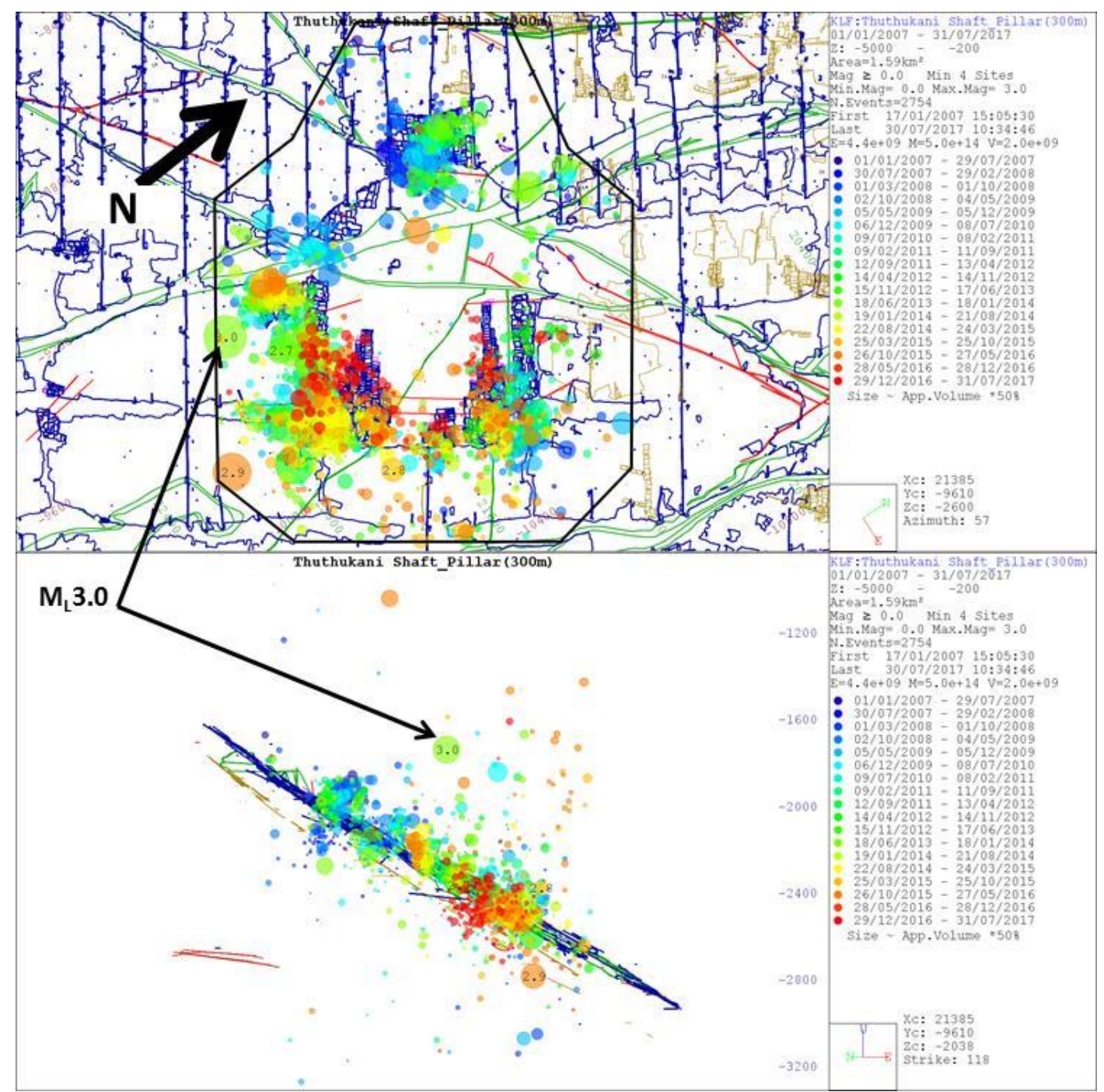

Figure 6 - (a) Plan and (b) Dip section view showing the location of seismic events with $M_{L} \geq 0$ between 1 January 2007 to 31 July 2017

Table III summarises the range of seismic events observed and recorded within the shaft pillar for the duration of the case study. Most seismic events are located on the reef. The depth locations of these seismic events are probably inaccurate, which is common in tabular mines since the seismic networks tend to be planar, rather than fully three dimensional. For this reason, the selection of seismic events for these analyses was carried out in plan-view and the elevation was ignored. Two-thirds of the larger magnitude events $\left(\mathrm{M}_{\mathrm{L}} \geq 2\right)$ locate on the edge of the shaft pillar due to the highly stressed abutments. Only one $\mathrm{M}_{\mathrm{L}} \geq 2$ seismic event was located within the shaft pillar and this occurred near the intersection of geological structures. 
Table III. Seismic events categorised according to their magnitudes and cumulative energy, moment and apparent volume in various magnitude bins

\begin{tabular}{|c|c|c|c|c|}
\hline $\begin{array}{c}\text { Magnitude } \\
\text { range }\end{array}$ & $\begin{array}{c}\text { Number } \\
\text { of events }\end{array}$ & $\begin{array}{c}\Sigma \text { Energy } \\
\mathbf{( M J )}\end{array}$ & $\begin{array}{c}\Sigma \text { Moment } \\
\left(\mathbf{1 0 ^ { 1 2 }} \mathbf{N m}\right)\end{array}$ & $\begin{array}{c}\Sigma \text { App. Volume } \\
\left(\mathbf{1 0}^{6} \mathbf{m}^{3}\right)\end{array}$ \\
\hline $0.0-1.0$ & 2489 & 678.68 & 92.30 & 855.06 \\
\hline $1.0-2.0$ & 372 & 1336.18 & 192.09 & 817.41 \\
\hline $2.0-3.0$ & 34 & 2305.70 & 205.22 & 398.20 \\
\hline$>3.0$ & 1 & 322.00 & 38.90 & 71.20 \\
\hline Total & $\mathbf{2 ~ 8 9 6}$ & $\mathbf{4} \mathbf{6 4 2 . 5 6}$ & $\mathbf{5 2 8 . 5 0}$ & $\mathbf{2 1 4 1 . 8 7}$ \\
\hline
\end{tabular}

\section{Shaft pillar production}

Production data for the Thuthukani shaft pillar from 1 January 2007 to 31 July 2017 (The selected period of analysis) is shown in Figure 7. Mining in the area has already contributed more than $204000 \mathrm{~m}^{2}$ of ore production with a monthly average of $1608 \mathrm{~m}^{2}$. It should be noted that while the monthly production was variable (e.g. production declined steeply from July 2011 to Nov 2012), the cumulative production was roughly linear (See Figure 8). Both the production data and the associated seismicity were analysed for the period to determine any changes in seismic response to production (See Figure 7). Production is measured in square meters $\left(\mathrm{m}^{2}\right)$, but the volume $\left(\mathrm{m}^{3}\right)$ of the extracted ore can easily be estimated using an average stoping height of $1.2 \mathrm{~m}$. Seismic activity is measured in the number of $\mathrm{M}_{\mathrm{L}} \geq 0$ events per month. A 3-sample moving average was used to smooth the graphs and to highlight the trends in the data.

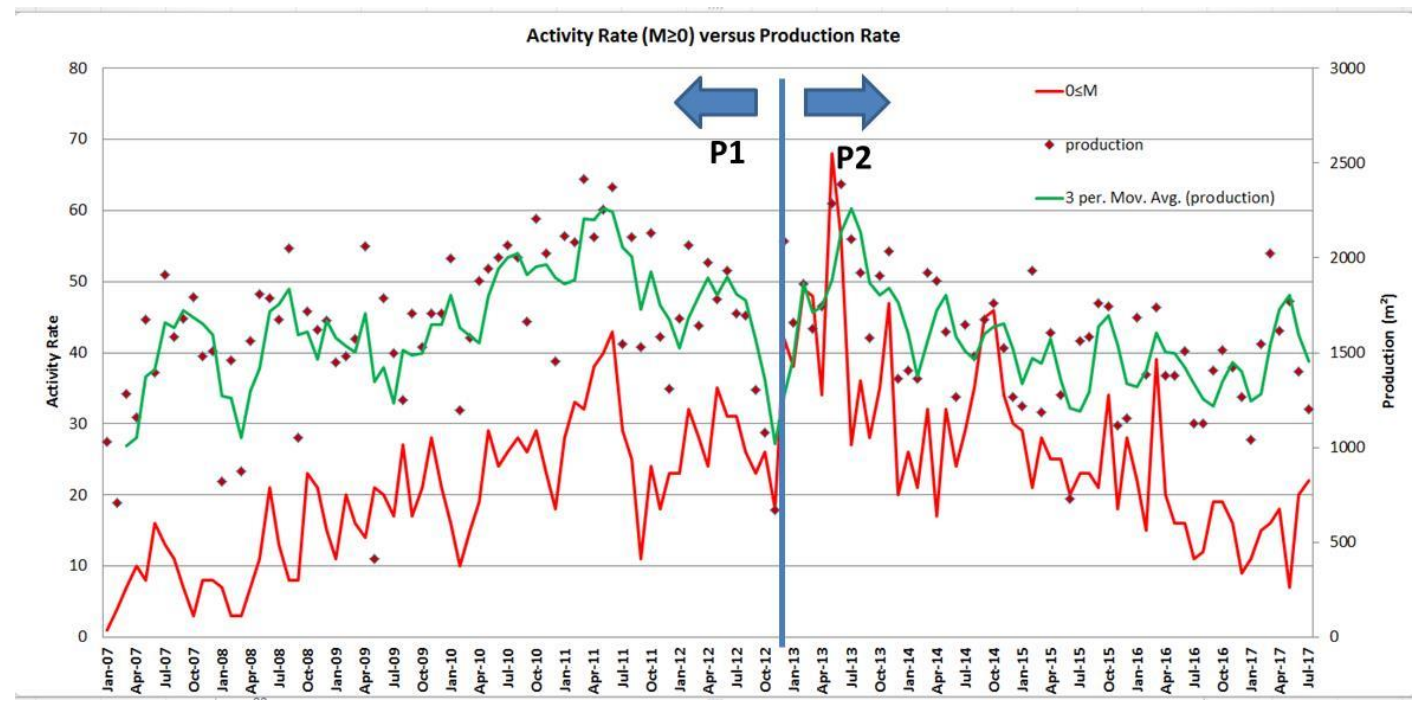

Figure 7 - Monthly production volume and seismic activity from 1 January 2007 to 31 July 2017.

Green line: smoothed production in $\mathrm{m}^{2}$; Diamonds: Actual production;

Red line: seismic activity in number of $M_{L} \geq 0$ events per month

\section{Seismic response analysis}

The seismic response to production is assessed to distinguish changes in the seismic response in the area of interest. Seismic potency $(P)$ is the parameter that is very useful for this purpose. The seismic potency per unit area mined was calculated as defined by Mendecki (2016):

$$
P=\frac{M_{0}}{G}=A d
$$


where $M_{0}=$ seismic moment, $G=$ modulus of rigidity $(30 \mathrm{GPa}), A=$ area of slip $\left(\mathrm{m}^{2}\right)$ and $d=\operatorname{slip}$ displacement $(\mathrm{m})$.

Seismic potency $\left(\mathrm{m}^{3}\right)$ could be considered as the volume of shear displacement associated with a seismic event. The cumulative seismic potency and production are plotted against time for the entire shaft pillar area (See Figure 8). The cumulative production is fairly linear, while the seismic potency is more variable, showing some significant changes, notably in November 2012 and January 2016. The correlation coefficient $\left(\mathrm{R}^{2}=0.481\right)$ indicates a moderate positive relationship between seismic activity and production throughout the entire period, indicating that production plays a major role in controlling seismicity.

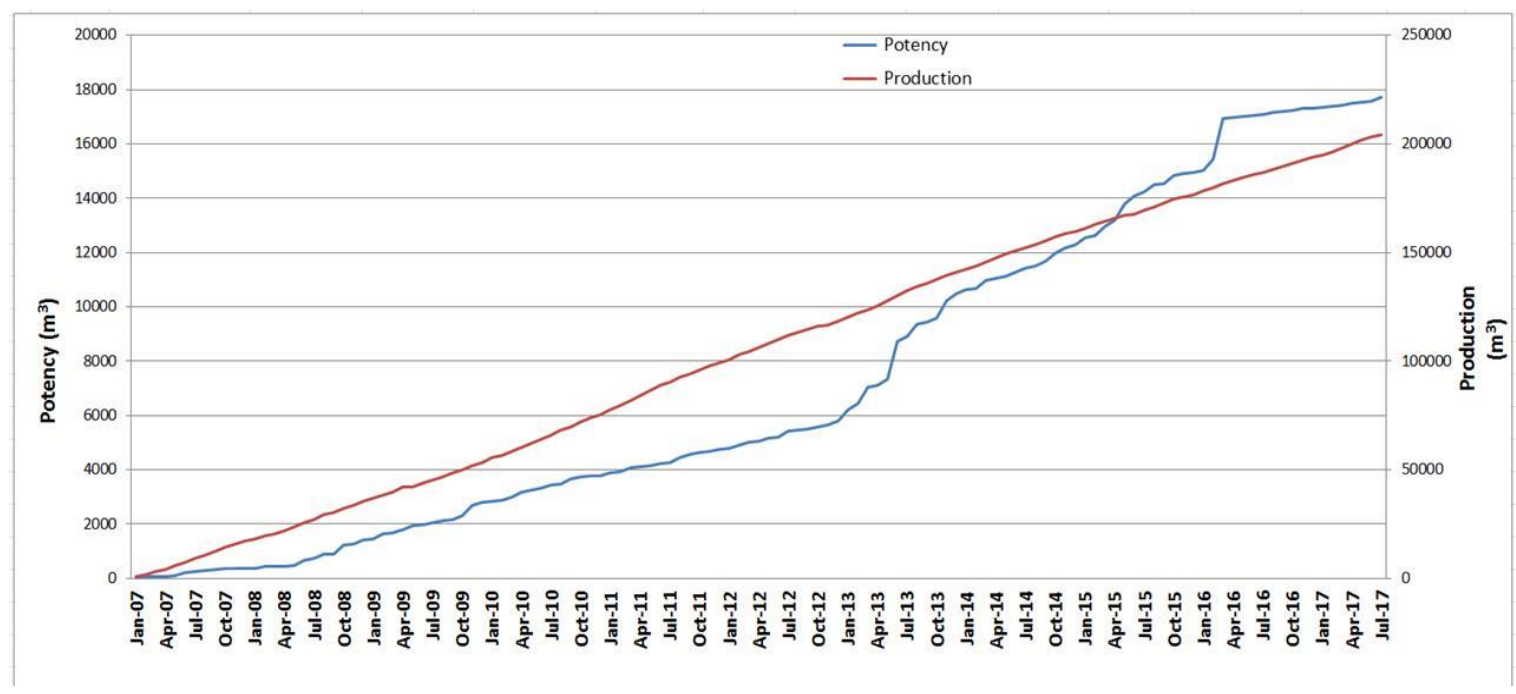

Figure 8. Seismic Potency and Cumulative Production from 1 January 2007 to 31 July 2017

Two periods with differing seismic responses were identified and compared, namely Period 1 (1 January 2007 to 30 November 2012) and Period 2 (1 December 2012 to 31 Jul 2017; see Figure 7, Figure 8 and Figure 9). The slope of the line in Figure 9 indicates the seismic response to production during the specific period: the steeper the slope, the more hazardous the seismic response was deemed to be. Period 2 (Blue line in Figure 9) has a steeper slope (0.1435) than Period $1(0.052$, brown line in Figure 9. 


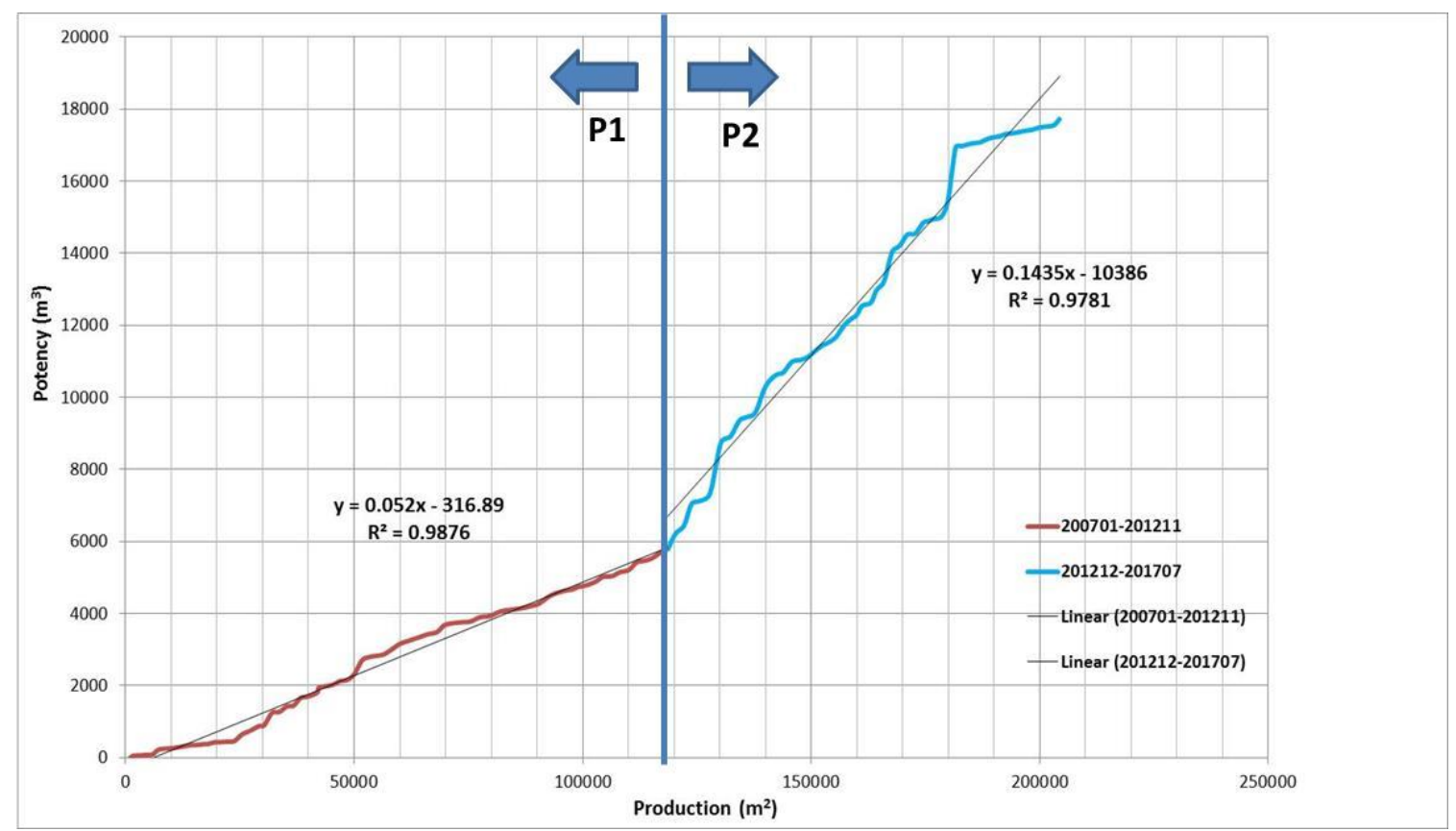

Figure 9. Seismic Potency versus production indicating the change in the seismic response of the rock mass to mining from period P1 (1 January 2007- 30 November 2012) to period P2 (1 December 2012- 31 July 2017)

The production $\left(\mathrm{V}_{\mathrm{m}}\right)$ and seismic potency $(\mathrm{P})$ during Period $1(\mathrm{P} 1)$ and Period $2(\mathrm{P} 2)$ are summarised in Table IV. The seismic hazard is estimated by finding the ratio between $\mathrm{V}_{\mathrm{m}}$ and $\mathrm{P}$. It is interesting to note that the average monthly production in P1 is higher than in P2, and the ratio of potency to production is greater in P2. P2 stands out as being of higher seismic hazard when compared to P1. The high level of seismicity within the shaft pillar in P2 is alarming, and the reason for the increase is still not fully understood and is the subject of further investigation.

Table IV. Seismic Potency versus Production

\begin{tabular}{|l|c|c|c|c|}
\hline \multirow{2}{*}{} & \multicolumn{2}{|c|}{ P1 (1/1/2007 - 30/11/2012 = 71 months) } & P2 (1/12/2012-31/7/2017 = 56 months) \\
\cline { 2 - 5 } & Production $\mathbf{V}_{\mathbf{m}}\left(\mathbf{m}^{3}\right)$ & Potency $\mathbf{P}\left(\mathbf{m}^{3}\right)$ & Production $\mathbf{V}_{\mathbf{m}}\left(\mathbf{m}^{3}\right)$ & Potency $\mathbf{P}\left(\mathbf{m}^{3}\right)$ \\
\hline Monthly & 1970.1 & 79.7 & 1880.2 & 215.5 \\
\hline Annual & 23641.8 & 956.4 & 22562.0 & 2586.1 \\
\hline Total & 139880.4 & 5658.7 & 105289.2 & 12068.3 \\
\hline P:V $V_{\mathbf{m}}$ & \multicolumn{2}{|c|}{$\mathbf{0 . 0 4 0}$} & \multicolumn{3}{c|}{$\mathbf{0 . 1 1 5}$} \\
\hline
\end{tabular}

During the first period (P1), there was a large degree of scattering in the locations of the seismic events, while during the second period (P2) the seismicity was concentrated in the southern portion of the shaft pillar where the mining was taking place (See Figure 9). In both periods, the largest seismic events were located on the geological structures and abutments of the mining areas (Figure 6). The main features of these two mining periods are summarized below:

Period 1: This period spans 2130 days and contains $2 \mathrm{M}_{\mathrm{L}} \geq 2.5$ seismic events, $11 \mathrm{M}_{\mathrm{L}} \geq 2.0$ events, 60 $\mathrm{M}_{\mathrm{L}} \geq 1.5$ events, $177 \mathrm{M}_{\mathrm{L}} \geq 1.0$ events, $496 \mathrm{M}_{\mathrm{L}} \geq 0.5,1317 \mathrm{M}_{\mathrm{L}} \geq 0.0$ events and $59,778 \mathrm{M} \geq-3.0$ events. The volume-mined is $139.9 \times 10^{3} \mathrm{~m}^{3}$ and the cumulative seismic potency is $5.7 \times 10^{3} \mathrm{~m}^{3}$; the ratio of volumemined to seismic potency is thus $\sum \mathrm{P} / \mathrm{V}_{\mathrm{m}}=0.040$. The largest seismic events occurred on 16 June 2008 and 04 November 2009, both with $\mathrm{M}_{\mathrm{L}}=2.5$. 
Period 2: This period spans 1680 days and contains $4 \mathrm{M}_{\mathrm{L}} \geq 2.5$ seismic events, $24 \mathrm{M}_{\mathrm{L}} \geq 2.0$ events, $81 \mathrm{M}_{\mathrm{L}}$ $\geq 1.5$ events, $226 \mathrm{M}_{\mathrm{L}} \geq 1.0$ events, $627 \mathrm{M}_{\mathrm{L}} \geq 0.5,1531 \mathrm{M}_{\mathrm{L}} \geq 0.0$ events and 49,111 M $\geq-3.0$ events. The volume-mined is $105.3 \times 10^{3} \mathrm{~m}^{3}$ and the cumulative seismic potency is $12.1 \times 10^{3} \mathrm{~m}^{3}$. The ratio of cumulative seismic potency to volume-mined for Period 2 is $\sum \mathrm{P} / \mathrm{V}_{\mathrm{m}}=0.115$, almost three times the ratio in Period 1, indicating an increased seismic hazard in the shaft pillar area. The largest seismic event, $\mathrm{M}_{\mathrm{L}}=3.0$, occurred on 26 June 2013 close to the abutment of the shaft pillar.

\section{Seismic hazard}

The data indicate that events of $\mathrm{M}_{\mathrm{L}} \geq 0.6$ adversely affected panels within the area of interest. During the first period (P1) 443 seismic events of $M_{L} \geq 0.6$ were recorded; 22 caused damage. The second period P2 recorded 519 events of $\mathrm{M} \geq_{\mathrm{L}} 0.6$; 18 caused damage.

In mine seismology, seismic hazard is defined as the probability of occurrence within time $\Delta \mathrm{T}$ of a potentially damaging event (e.g. $\mathrm{M}_{\mathrm{L}} \geq 0.0$ ). Hazard assessments in the mining areas are of great assistance in evaluating both the frequency and intensity of seismic events. This allows the adoption and implementation of measures to be taken in reducing both the risks and associated damages to seismicity. The probabilities of occurrence in the shaft pillar are estimated by assuming a stationary Poisson process Mendecki ( 2016):

$$
\operatorname{Pr}(\geq P, \Delta T)=1-\exp \left[-\frac{\Delta T}{T} N(\geq P)\right]
$$

where $\mathrm{T}$ is the observed time and $N(\geq P)$ is the number of seismic events during the respective time period. Table V summarize the intermediate- and long-term probabilities of occurrence in the time domain comparing both Period 1 and Period 2, respectively. The probability of occurrence of a seismic event of any given magnitude obviously increases as the period increases.

Table V. Intermediate-term probabilities of occurrence for Period 1 and Period 2

\begin{tabular}{|lllllll|}
\hline & \multicolumn{5}{c|}{ Probabilities (Period 1/Period 2) } \\
& $\mathbf{M}_{\mathbf{L}}=\mathbf{0 . 5}$ & $\mathbf{M}_{\mathbf{L}}=\mathbf{1 . 0}$ & $\mathbf{M}_{\mathbf{L}}=\mathbf{1 . 5}$ & $\mathbf{M}_{\mathbf{L}}=\mathbf{2 . 0}$ & $\mathbf{M}_{\mathbf{L}}=\mathbf{2 . 5}$ \\
\hline$\Delta \mathbf{T}=\mathbf{3 0}$ days & $0.997 / 1.000$ & $0.871 / 0.967$ & $0.495 / 0.712$ & $0.182 / 0.354$ & $0.031 / 0.126$ \\
\hline$\Delta \mathbf{T}=\mathbf{9 0}$ days & $1.000 / 1.000$ & $0.998 / 1.000$ & $0.871 / 0.976$ & $0.453 / 0.730$ & $0.009 / 0.333$ \\
\hline$\Delta \mathbf{T}=\mathbf{1 8 0}$ days & $1.000 / 1.000$ & $1.000 / 1.000$ & $0.983 / 0.999$ & $0.701 / 0.927$ & $0.017 / 0.555$ \\
\hline$\Delta \mathbf{T}=\mathbf{3 6 5}$ days & $1.000 / 1.000$ & $1.000 / 1.000$ & $1.000 / 1.000$ & $0.910 / 0.995$ & $0.031 / 0.802$ \\
\hline$\Delta \mathbf{T}=\mathbf{2}$ years & $1.000 / 1.000$ & $1.000 / 1.000$ & $1.000 / 1.000$ & $0.992 / 1.000$ & $0.053 / 0.961$ \\
\hline$\Delta \mathbf{T}=\mathbf{5}$ years & $1.000 / 1.000$ & $1.000 / 1.000$ & $1.000 / 1.000$ & $1.000 / 1.000$ & $0.849 / 1.000$ \\
\hline
\end{tabular}

In Period 1, the probability that a seismic event with $\mathrm{M}_{\mathrm{L}} \geq 1.0$ occurs somewhere in the shaft pillar during a one-month period is $\operatorname{Pr}[\geq P, \Delta T]=0.871$; while the corresponding probability for Period 2 is even higher, 0.967 . The probability that a seismic event of $\mathrm{M}_{\mathrm{L}} \geq 2.0$ occurs within six-months in Period 1 is 0.701 ; while it is 0.927 in Period 2.

The parameters used to reflect the seismic hazard for both Period 1 and Period 2 are summarized in Table VI. Period 2 indicates a slightly higher probability of $M_{L} \geq 1$ events (hence a shorter recurrence time) with a seismic event of $M_{L} \geq 1$ expected to occur in the Thuthukani shaft pillar every 9 days, on average. The maximum credible magnitude $\left(\mathrm{M}_{\max }\right)$ is greater in $\mathrm{P} 2$ than $\mathrm{P} 1$. This indicates an increase in seismic hazard. 
Table VI. Comparison of seismic hazard for both Period 1 and Period 2

\begin{tabular}{|l|c|c|}
\hline Seismic Parameter & Period 1 (P1) & Period 2 (P2) \\
\hline $\mathrm{M}_{\max }$ Recorded & 2.5 & 3.0 \\
(Date of occurrence) & $(16 / 7 / 2008 ; 4 / 11 / 2009)$ & $(26 / 6 / 2013)$ \\
\hline $\mathrm{M}_{\max }$ expected & 2.70 & 3.20 \\
\hline b-value & 1.05 & 0.92 \\
\hline Recurrence time $\mathrm{M} \geq 1$ (months) & 0.4 & 0.3 \\
\hline Probability $\mathrm{M} \geq 1$ (per month) & $91.1 \%$ & $97.8 \%$ \\
\hline No. of events $\mathrm{M} \geq 1$ & 178 & 221 \\
\hline Events occurring off-shift & $36 \%$ & $61 \%$ \\
\hline
\end{tabular}

Hazard is the likelihood of a potentially damaging event occurring; while risk takes the consequences of a damaging event into account. This is governed by the fragility of geological structures as well as the exposure of workers and other assets. The majority of $M_{L} \geq 0.0$ events occur on-shift (Blue lines and green bars in Figure 10) in both periods; the second period indicates a 25\% improvement of events occurring off-shift (red bar graph), which limits the exposure of mine workers to injury (See Figure 10).
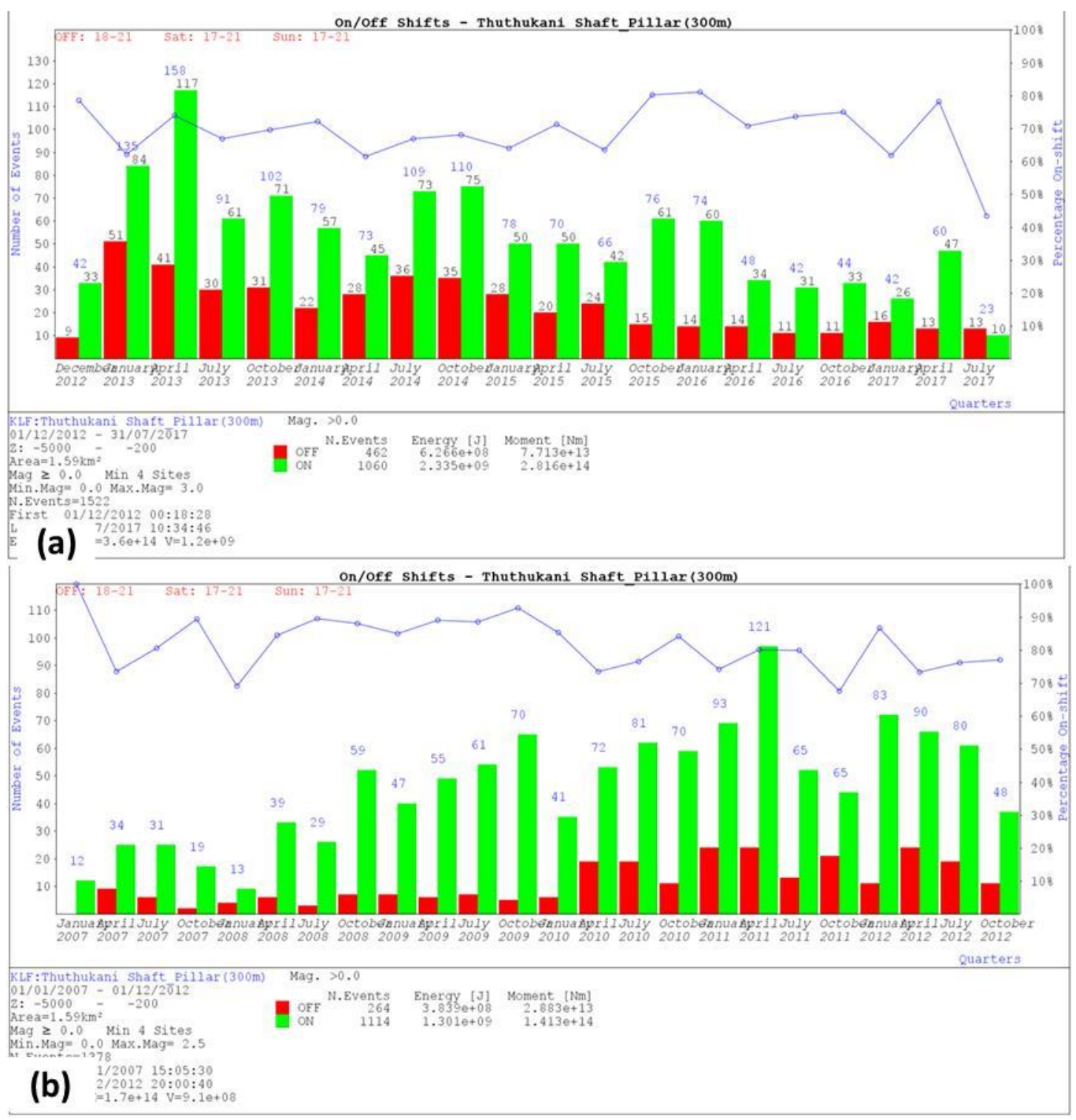

Figure 10. On-off shift recorded seismic events for (a) Period 1 (a) and (b) Period 2 


\section{Changing seismic response to mining}

The seismic response to the mining in any ore body may change as a result of changes in extraction sequences and methods. The changes in the seismic response at the Thuthukani pillar extraction, as manifested by the increase in a number of larger seismic events, have been evident since October 2010.

Figure 11 shows the magnitude-time history graph for events $\mathrm{M}_{\mathrm{L}}=0.0$, and incorporates the cumulative number of large seismic events between January 2007 and July 2017. The magnitude-time history analysis (i.e., how magnitude varies with time) of clusters of seismic events in space provides valuable insight into the seismic hazard. The magnitude-time graph summarises a number of items of valuable information. It shows the largest event to occur within a given period, which is an indicator of relative seismic hazard. It also graphs the cumulative number of seismic events, revealing changes in the rate of occurrence. A significant change in the number of large events $M \geq 1.5$ is noticeable from October 2010 to April 2015 followed by a decrease in their occurrence (See Figure 11).

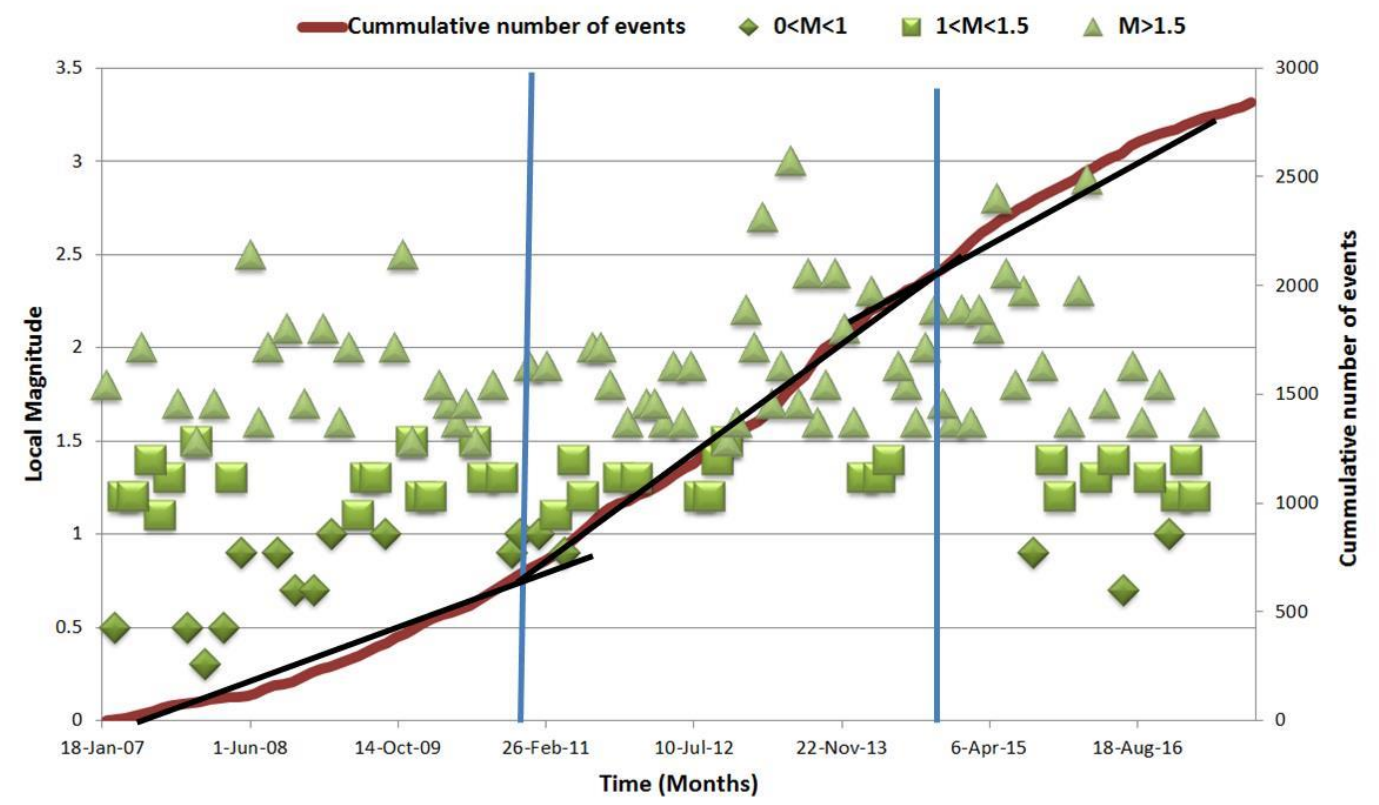

Figure 11. Event time history and the cumulative number of events $M_{L} \geq 0.0$ for a period 1 January 2007 to 31 July 2017. Green symbols indicate the maximum event magnitude in a given month

When the extraction started at the top of the shaft pillar the rock-mass responded with large seismic events up to $\mathrm{M}_{\mathrm{L}} 3$. As mining progressed, the number of events with magnitude greater than $\mathrm{M}_{\mathrm{L}} 2$ increased until early 2016. This was followed by an apparent decrease. The reason for this response is not currently known, and is the subject of further investigations.

\section{DISCUSSION}

During a decade of seismic monitoring, large amounts of information have been recorded within the shaft pillar. The transition from a seismically-quiet shaft pillar to one exhibiting moderate-to-high levels of seismicity has occurred as mining progressed within the pillar. Analysis of the time history graph shows that seismic events are concentrated in time, driven by the concentration of mining activities over a certain period. The combined effects of mining configuration (such as type of mining, lead-lags), complex geology, rock mass properties, active geological structures, the concentration of mining, the volume of mining, numbers of mining crews and the increase in depth, all lead to changes in the rock mass response. Due to the high seismic activity within the shaft pillar, the volume of mining has been reduced from $1650 \mathrm{~m}^{2}$ and capped at $1200 \mathrm{~m}^{2}$ per month. This could be reduced even further, depending on the seismic response. 
Analysis of the seismic response revealed two stages, P1 (1 January 2007 to 30 November 2012) and P2 (1 December 2012 to 31 July 2017). P2 seems to be more hazardous period, as compared to P1. A significant increase in the ratio of seismic potency to production is observed in P2. Cumulative frequency magnitude and cumulative frequency potency distributions were determined for both periods. P2 highlighted the severity of seismic response within the shaft pillar. An assessment of seismic hazard revealed that the probability of occurrences for different ranges magnitudes was higher in P2 compared to P1.

Magnitude time-history analyses can sometimes indicate different stages in the seismic response to mining it indicates stages in timeline that are characterised by several factors, and is influenced by extraction volume, mining geometry, mining layout and mining practises used within the shaft pillar. These stages include:

1. Quiet stage: This is when relatively few seismic events occur, and minimal damage is done to the surrounding rockmass. The few seismic events are generally of low magnitude and triggered by blasting. The seismic hazard at this stage is low.

2. Transition stage: During this stage, seismicity increases with stoping activity and the magnitude of these seismic events is expected to increase. This is the stage where large seismic events become more common, resulting into an increase in the seismic hazard from low to medium hazard.

3. Active stage: The number of large events increases. Large seismic events are more likely to cause substantial damage to the mining infrastructures. The production in this stage may decrease owing to rockburst damage. The design and sequencing of layouts to manage the seismic hazard is crucial.

Seismicity data indicate the Thuthukani shaft pillar is transforming from the quiet stage into the transition stage. The layout used to extract the remaining resources within the shaft pillar will be continuously reviewed in an attempted to mitigate or decrease seismic risk in identified hazardous area (hot spots). In-stope support practices are being revised in an attempt to ensure stoping and development ends are being supported adequately to ensure mining safely.

\section{CONCLUSIONS}

The seismic database collected since 2007 has proved invaluable in understanding the seismic response to mining within the main shaft pillar. The evaluation of this seismic response was carried out using seismic statistical hazard parameters and production. Production positively correlates $(R=0.481)$ with seismicity of $M \geq 0$. Though the production rate was essentially constant, on average the seismic hazard within the shaft pillar kept on increasing as mining advanced. Risk mitigation measures were regularly reviewed by Kloof Operations.

The study shows that the seismic hazard has increased during the extraction of the Thuthukani shaft pillar. An assessment of seismic hazard using intermediate term probability of occurrence indicates an increase in the rate of occurrence of $M \geq 1.0$ seismic events in period 2 as compared to period 1 . The $M_{\max }$ value of 3.2 is higher for Period 2 as compared to $\mathrm{M}_{\max }$ of 2.7 during Period 1. In terms of seismic event statistics, 221 events of $M \geq 1$ indicated more instability for Period 2. The reasons however, leading to these changes during the extraction are not yet well known and will form part of further investigation.

\section{ACKNOWLEDGEMENTS}

The Management of Sibanye-Stillwater is gratefully acknowledged for permission to publish this paper. Ricardo Ferreira is thanked for providing valuable comments and suggestions. 


\section{REFERENCES}

Chen, J.F. (2007). Results of rock property tests. Rocklab Report 2007-OHS- Research-Works-03. Rocklab. Pretoria, South Africa.

Dankert, B. T., and Hein, K. A. A. (2010). Evaluating the structural character and tectonic history of the Witwatersrand Basin: Precambrian Research, 177, 1-22.

Jager, A.J. and Ryder, J.A. (1999). Rock Engineering Practice for Tabular Hard Rock Mines. The Safety in Mines Research Advisory Committee (SIMRAC), Johannesburg.

Manzi, M. S. D., Hein, K. A. A., King, N. and Durrheim, R. J. (2013). Neoarchaean tectonic history of the Witwatersrand Basin and Ventersdorp Supergroup: new constraints from high-resolution 3D seismic reflection data. Tectonophysics, 590, 94-105.

Maritz, A.J., Greyling, P.A., Geyser, D. (2007). Extraction of the shaft pillar on the VCR horizon Kloof Main Shaft Complex. Challenges in Deep and High Stress Mining, Potvin, Y., Hadjigeorgiou, J. and Stacey, D. (eds), Australian Centre for Geomechanics, pp. 105-111.

Mendecki, A. J. (2016). Mine Seismology Reference Book: Seismic Hazard. Institute of Mine Seismology, ISBN 978-0-9942943-0-2, www.imseismology.org/msrb/, 1 edition.

http://www.imseismology.org/msrb/.

Naicker, N. (2013). Application of seismic information in the mining design and monitoring of the KDCEast shaft Pillar. Proceedings of the Eighth International Symposium on Rockbursts and Seismicity in Mines, Saint Petersburg - Moscow, Russia, 1-7 September 2013, Malovichko, A. and Malovichko, D. (eds), Geophysical Survey of the Russian Academy of Sciences and Mining Institute of Ural Branch of Russian Academy of Sciences, pp. 395-412.

Van der Heever, P and Ryder, J.A. (2007). Characterisation of the Westonaria Formation at Main Shaft, Kloof Gold Mine. Consultancy Report. Groundwork. Johannesburg, South Africa.

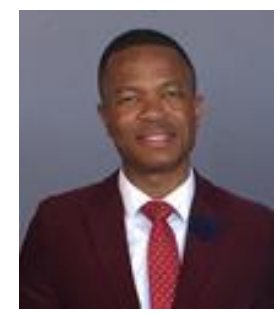

\section{Richard Masethe}

Sibanye-Stillwater

Richard has been actively involved in seismology department overseeing different seismic systems. He holds a BSc Hons (Geophysics), GDE (Rock Engineering), MSc (Rock Engineering) and currently doing his $\mathrm{PhD}$ (Geophysics) at the University of the Witwatersrand. He started his career in 2007 as a graduate rock engineering trainee in Goldfields. He is currently working for Sibanye-Stillwater Seismic Department, specializing in mine seismology. 
